\title{
STUDY OF COAL MICROBIOCENOSIS FOR DEVELOPMENT OF BIOTECHNOLOGICAL METHOD FOR ITS DESULFURISATION
}

\author{
Iryna Blayda ${ }^{1,}$, Tetyana Vasylieva ${ }^{1}$, Nataliia Vasylieva ${ }^{1}$, \\ Valentyna Khytrych $^{1}$, Svitlana Shuliakova ${ }^{1}$
}

https://doi.org/10.23939/chcht15.01.074

\begin{abstract}
A presence of microscopic fungi, heterotrophic bacteria, as well as neutrophilic and acidophilic chemolitotrophic bacteria was determined in coal microbiocenosis. The largest and most active towards pyrite sulfur removal is the Acidithiobacillus genus. Heterotrophic bacteria have the biggest potential when it comes to removal of organic sulfur. Preceding treatment of coal with "silicate" bacteria from the Bacillus genus will allow to use coal microbiocenosis for its biodesulfurisation at its full potential.
\end{abstract}

Key words: coal, microbiocenosis, desulfurization, heterotrophic bacteria, acidophilic chemolitotrophic bacteria.

\section{Introduction}

One of the most important characteristics of coal, which affects its quality, caloric characteristics and, therefore, price is the sulfur content. Due to the geochemical features of the formation of coal deposits, the total sulfur $\left(\mathrm{S}_{\text {tot. }}\right)$ is present in coal as inorganic or pyrite $\left(\mathrm{S}_{\mathrm{pyr}}\right)$, organic $\left(\mathrm{S}_{\mathrm{org}}\right)$, sulfate $\left(\mathrm{S}_{\mathrm{sul}}\right)$ and elemental $\left(\mathrm{S}_{0}\right)$. Generally, the share of organic sulfur accounts for $50.0 \%$, and the share of pyrite - up to $60.0 \%$ of the total amount of sulfur in coal depending on the deposit. The improvement of the quality of coal raw materials for highquality coking and energy coal, which is in demand on the market, is achieved by enriching various physical and chemical methods: gravity, magnetic separation, electric separation, flotation, and others [1,2].

With the development of biotechnology, more attention is paid to environmentally safe and resourcesaving microbiological methods for sulfur reducing in coal - biodesulfurization [3-5]. In this case, different microbiological approaches should be used to remove pyrite and organic sulfur. Literature data analysis suggests that mesophilic and moderately thermophilic acidophilic

\footnotetext{
${ }^{1}$ Odessa I.I. Mechnikov National University

2, Dvoryanska St., 65082 Odessa, Ukraine

iblayda@ukr.net

(C) Blayda I., Vasylieva T., Vasylieva N., Khytrych V., Shuliakova S., 2021
}

chemolithotrophic bacteria (ACB) [3-6] dominate in the removal processes of inorganic sulfur from coal, in particular, representatives of the genera Acidithiobacillus, Lepthospirillum, Sulfobacillus which use ferrous iron, sulfur and its compounds as a source of energy for their livelihoods. Due to the above, they have found wide application in the leaching of metals from natural sulfide ores with high content of valuable components $[5,7,8]$. Regarding the removal of organic sulfur from coal, special attention is paid to the group of heterotrophic microorganisms, in particular the genera Pseudomonas, Brevibacterium, Rhodococcus, Bacillus, which are capable of destroying carbon-sulfur bonds in heterocyclic organic sulfur compounds such as thiophene and its derivatives $[6$, $9,10]$.

In this area of research on biodesulfurization of coal, the main attention is paid to the use of pure cultures of microorganisms, typical and collectible strains, as well as isolated from specific sources - various samples of coal and drainage acidic mine waters. There is practically no data on the application of the associations of mixed cultures and consortia of their own microbiotypes of coal substrates, although the activity of such communities is well established and widely used in the bioleaching of metals from sulfide ores and man-made substrates due to the action of syntrophic relations between individual groups of microorganisms in a community $[5,7,8]$.

The purpose of this work is to study the qualitative and quantitative composition of coal microbiocenosis, as well as to establish the activity of its individual representatives in the removal of inorganic and organic sulfur from coal.

\section{Experimental}

The research objects were groups of microorganisms, isolated from the samples of coal from one of the mines of Lviv-Volynsky coal basin. Samples (more than 30 in total) were taken during 2016-2018 years out of averaged samples of freshly mined coal. Averaged concentrations of sulfur in research samples are as follows, 
$\%: \mathrm{S}_{\text {tot. }} .2 .86 ; \mathrm{S}_{\text {pyr. }} \quad 1.46 ; \mathrm{S}_{\text {org. }} \quad 1.08$. Microbiological researches included qualitative and quantitative evaluation of primary physiological groups of microorganisms, which make up the coal microbiocenosis. Heterotrophic, neutrophilic, acidophilic chemolitotrophic bacteria and fungi were extracted from the cumulative culture, which was obtained via standard methods using nutrient medium for different groups of microorganisms. The composition of nutrient media is presented in Table $1[11,12]$. As a source of energy, a $\mathrm{Na}_{2} \mathrm{~S}_{2} \mathrm{O}_{3}$ (TS) thiosulfate was added at the concentration of $5.0 \mathrm{~g} / \mathrm{dm}^{3}$ to the mineral background of media 9K, 150a and Beyerinck; the salt of ferrous iron $\mathrm{FeSO}_{4} \cdot 7 \mathrm{H}_{2} \mathrm{O}$ was added to $9.9 \mathrm{~K}^{*}$ and 882 media at the concentrations of $44.5,30.0$ and $20.0 \mathrm{~g} / \mathrm{dm}^{3}$, respectively. The cultivation of fungi and mesophilic (MP) bacteria was carried out at the temperature of $303 \pm 0.5 \mathrm{~K}$, moderately thermophilic (MTP) - at the temperature of $318 \pm 0.5 \mathrm{~K}$, the ratio of solid and liquid phases was maintained as $S: L=1: 10$, the cultivation term was 3-7 days, depending on the group of microorganisms. The presence of sporeforming bacteria was determined after heat treatment at the temperature of $353 \pm 0.5 \mathrm{~K}$ for $15 \mathrm{~min}$. Changes in $\mathrm{pH}$ values, the appearance of turbidity and surface film pointed to the development of microorganisms in cumulative cultures. The number of bacterial cells was determined in recalculation on grams of coal by counting them in colonies, grown on agar medium after seeding of successive dilutions of bacterial suspensions. Cell morphology and colonies formed by them were studied using a Primo Star PC light microscope (Germany). The activity of individual representatives of microbiocenose was judged by the amount of sulfur remaining in the coal after its contact with the appropriate selective nutrient medium. Sterile coal and solutions were used as the control. Analysis on the content of total, pyrite and organic sulfur in coal was carried out according to standard methods ISO 334-92 and ISO 157:996. The reliability of the obtained results was evaluated according to Student's criterion with probability $\mathrm{p}<0.0$.

\section{Results and Discussion}

Numerous microscopic researches of coal of various ages prove that diverse groups of saprotrophic microorganisms (bacteria, mushrooms, yeast, actinomycetes) were living and evolving during all of the geological periods of solid fuels establishment. It appears that the deep biosphere consists of members of all three existing domains bacteria, eukaryotes and archaea [10]. According to the results of the determination of the structure of microbiocenose samples of coal in the mines of the LvivVolynsky coal basin, a wide range of microorganisms of various physiological groups with a significant predominance of microscopic fungi, heterotrophic and acidophilic chemolithotrophic bacteria (Fig. 1) has been established. Quantitative indices of the established microbiocenosis of the investigated coal are presented in Table 2.

Table 1

\section{Composition of nutrient media $\left(\mathrm{g} / \mathrm{dm}^{3}\right)$ for detection of groups of microorganisms of coal of Lviv-Volynsky basin}

\begin{tabular}{|c|c|c|c|c|c|c|c|}
\hline Mineral components & \multicolumn{7}{|c|}{ Nutrient media $[11,12]$} \\
\hline & A-27 & Czapek & $9 \mathrm{~K}$ & $9 \mathrm{~K}^{*}$ & $150 \mathrm{a}$ & Beyerinck & 882 \\
\hline $\mathrm{KH}_{2} \mathrm{PO}_{4}$ & & & 0.50 & 0.05 & 0.50 & & 0.027 \\
\hline$\left(\mathrm{NH}_{4}\right)_{2} \mathrm{SO}_{4}$ & & & 3.00 & 0.45 & 3.00 & & 0.132 \\
\hline $\mathrm{MgSO}_{4} 7 \mathrm{H}_{2} \mathrm{O}$ & 0.50 & 0.50 & 0.50 & 0.50 & 0.50 & & \\
\hline $\mathrm{MgCl}_{2} \cdot 6 \mathrm{H}_{2} \mathrm{O}$ & & & & & & 0.10 & 0.053 \\
\hline $\mathrm{NH}_{4} \mathrm{Cl}$ & & & & & & 0.10 & \\
\hline $\mathrm{KCl}$ & & 0.50 & 0.10 & 0.05 & 0.10 & & \\
\hline $\mathrm{NaNO}_{3}$ & & 3.00 & & & & & \\
\hline $\mathrm{K}_{2} \mathrm{HPO}$ & & 1.00 & & & & & \\
\hline $\mathrm{Na}_{2} \mathrm{HPO}_{4}$ & 2.00 & & & & & 0.20 & \\
\hline $\mathrm{Ca}\left(\mathrm{NO}_{3}\right)_{2}$ & & & 0.01 & 0.014 & 0.01 & & \\
\hline $\mathrm{CaCl}_{2} 2 \mathrm{H}_{2} \mathrm{O}$ & & & & & & & 0.147 \\
\hline $\mathrm{FeCl}_{3}$ & 0.001 & 0.01 & & & & & \\
\hline $\mathrm{NaHCO}_{3}$ & & & & & & 1.00 & \\
\hline $\mathrm{CaCO}_{3}$ & 1.00 & & & & & & \\
\hline Quartz & 10.00 & & & & & & \\
\hline Sucrose & 5.00 & 30.00 & & & & & \\
\hline Yeast extract & & & & 0.02 & & & \\
\hline $\mathrm{pH}$ & $7.5-8.0$ & $6.6-7.2$ & $1.0-3.5$ & $1.8-4.0$ & $1.5-3.5$ & $4.5-8.5$ & $2.0-4.0$ \\
\hline
\end{tabular}


The number of bacterial cells in cumulative cultures obtained from coal, cells/gram

\begin{tabular}{|c|c|c|c|c|c|c|c|c|c|}
\hline \multirow{3}{*}{\multicolumn{3}{|c|}{$\begin{array}{l}\text { Heterotrophic } \\
\text { microorganisms }\end{array}$}} & \multirow{3}{*}{ 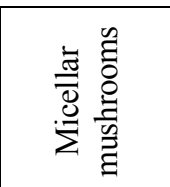 } & \multicolumn{5}{|c|}{ Chemilototrophic bacteria } & \multirow{3}{*}{ 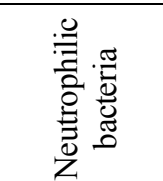 } \\
\hline & & & & \multicolumn{5}{|c|}{ Acidophilic } & \\
\hline & & & & \multicolumn{3}{|c|}{ Mesophilic } & \multicolumn{2}{|c|}{ Moderately thermophilic } & \\
\hline \multicolumn{10}{|c|}{ Medium } \\
\hline \multicolumn{2}{|c|}{ Horbenko } & \multirow[t]{3}{*}{ A-27 } & \multirow[t]{3}{*}{ Czapek } & \multicolumn{2}{|c|}{$9 \mathrm{~K}$} & 882 & $9 \mathrm{~K}^{*}$ & $150 \mathrm{a}$ & Beyerinck \\
\hline \multirow{2}{*}{$\begin{array}{l}\text { Spore- } \\
\text { forming }\end{array}$} & \multirow{2}{*}{$\begin{array}{c}\text { Non-spore- } \\
\text { forming }\end{array}$} & & & \multicolumn{6}{|c|}{ Sources of energy } \\
\hline & & & & $\mathrm{Na}_{2} \mathrm{~S}_{2} \mathrm{O}_{3}$ & $\mathrm{Fe}(\mathrm{II})$ & $\mathrm{Fe}(\mathrm{II})$ & $\mathrm{Fe}(\mathrm{II})$ & $\mathrm{Na}_{2} \mathrm{~S}_{2} \mathrm{O}_{3}$ & $\mathrm{Na}_{2} \mathrm{~S}_{2} \mathrm{O}_{3}$ \\
\hline$(3.0 \pm 0.5) \cdot 10^{6}$ & $(1.5 \pm 0.2) \cdot 10^{5}$ & $(6.0 \pm 0.1) \cdot 10^{2}$ & $(7.0 \pm 0.5) \cdot 10^{7}$ & $(3.0 \pm 0.1) \cdot 10^{3}$ & $(7.8 \pm 0.3) \cdot 10^{6}$ & $(8.0 \pm 0.2) \cdot 10^{3}$ & $(3.6 \pm 0.2) \cdot 10^{6}$ & $(1.5 \pm 0.1) \cdot 10^{2}$ & $(1.0 \pm 0.1) \cdot 10^{3}$ \\
\hline
\end{tabular}

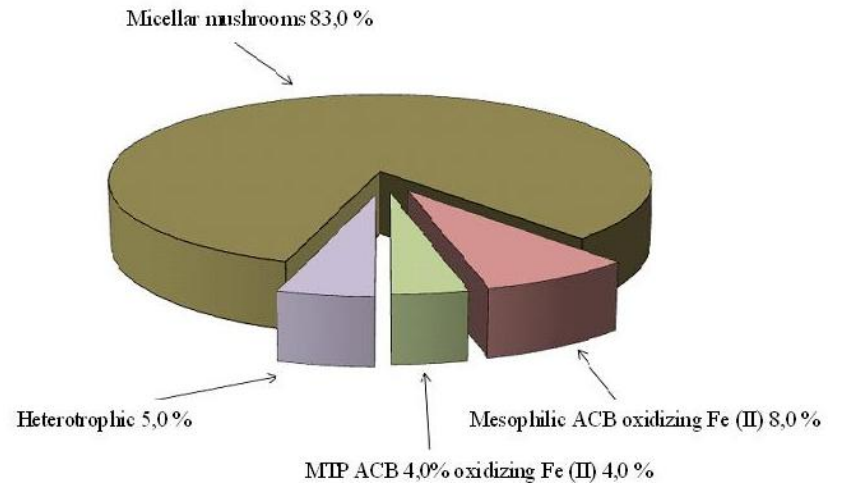

Fig. 1. Structure and number of dominant groups of microorganisms in microbiocenosis of coal

Microscopic fungi predominated in terms of quantity in the investigated coal microbiocenosis. The number of bacterial cells in the suspension was $(7.0 \pm 0.5) \cdot 10^{7}$ cells/gram. The medium of Czapek, which was used to obtain the cumulative culture of the micellar fungi, had been turning cloudy for three days, abundant gas formation was noted. On the agar medium, large white fluffy colonies dominated (Fig. 2a), on the surface of which the appearance of black colored pointy shapes could be seen (Fig. 2b), resembling heads with ripe spores. It can be assumed that these colonies belong to a fungus of a mold genus, which often appears on the soil and in mines [9]. It is known that the microscopic fungus grows well in warm, humid places, which include coal mines with a stable temperature and humidity regime. Thus, Aureobasidium and Penicillium isolates were isolated from the coal bulk in the amount of $10^{7}$ $10^{8}$ cells/gram, however, no pathogenic fungi, which are a direct threat to the health of workers, were determined in the air of coal mines [13].

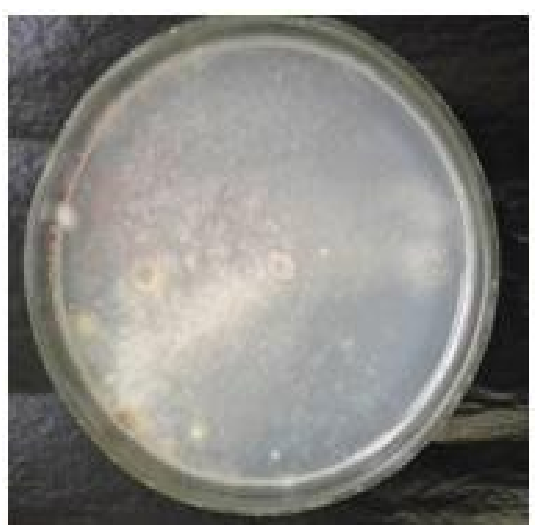

a)

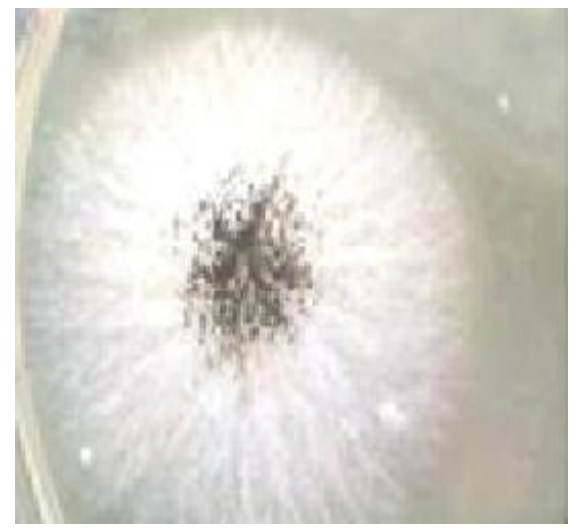

b)

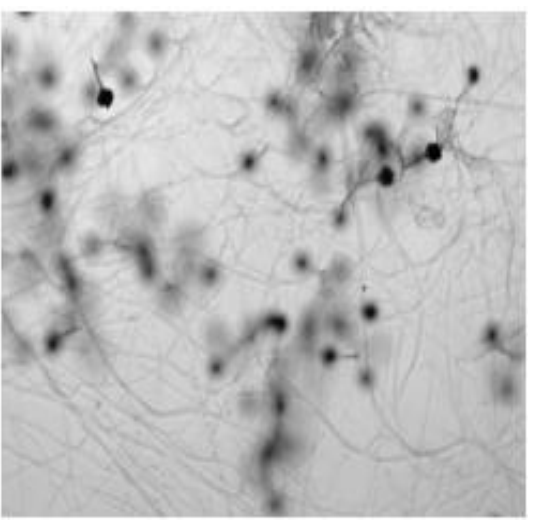

c)

Fig. 2. Colonies of mycelium fungi, which were grown on the agarized medium of Czapek at magnification of $30 \times($ a); $50 \times(b)$ and $100 \times(c)$ 
Heterotrophic bacteria, spore-forming and nonspore-forming, were detected in the microbiocenosis of the investigated coal in the amount of $(3.0 \pm 0.5) \cdot 10^{6}$ and $(1.5 \pm 0.2) \cdot 10^{5}$ cells/gram, respectively. After three days of cultivation on the selective for heterotrophs Horbenko medium, the cumulative culture looked rather turbid, light yellow with a white, sedimentary layer; on the surface, a white film, consisting of bacterial cells and coal dust, was recorded. When sowing a bacterial suspension on an agar medium, colonies of varying size and morphology were spotted: white flat with uneven edges wrinkled (Fig. 3, A), shiny and cream colored with an equal margin (Fig. 3, B); small, bright yellow (Fig. 3, C). This indicates a wide range of heterotrophic bacteria present in the samples of coal studied and suggests the presence of bacteria of the genera Pseudomonas, Bacillus, Flavobacterium, which does not contradict the available literature data $[13,14]$.

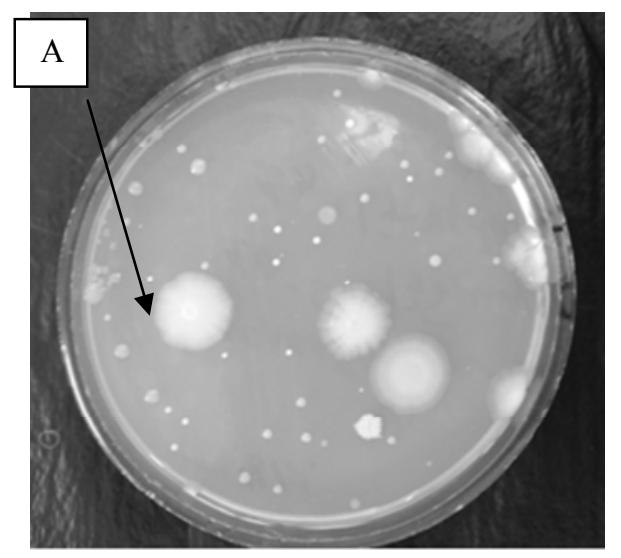

Among the heterotrophic bacteria, the so-called "silicate" bacteria of the Bacillus genus, which are capable of destroying various silicon compounds, natural silicates in particular, aluminosilicates and quartz, deserve special attention in terms of prospects for using in biodesulfurization of coal $[15,16]$. In the selective medium for "silicate" bacteria, the cells in the A-27 medium were extracted in a comparatively small amount of $(6.0 \pm 0.1) \cdot 10^{2}$ cells/gram, which in the colored microscopic preparation had the appearance of gram-positive rabies-like cells (Fig. 4a), and on the agar medium A-27 the cells formed uniform colorless transparent with an equal edge round colonies (Fig. $4 \mathrm{~b}$ ). The obtained results correspond to the available small-scale literary data on the presence of representatives of "silicate" bacteria in coal mines and acid mine waters, as well as their strong antagonistic activity, which represents itself in suppressing the growth of other heterotrophic bacteria [10].

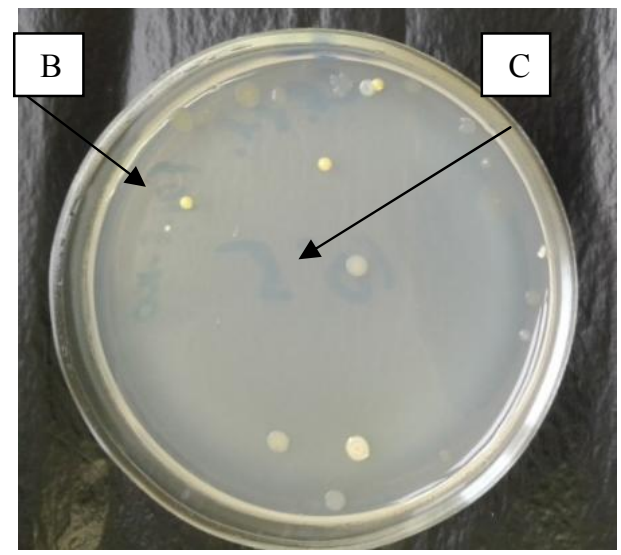

Fig. 3. Colonies of heterotrophic bacteria grown on Horbenko agar medium; magnification of $30 \times$

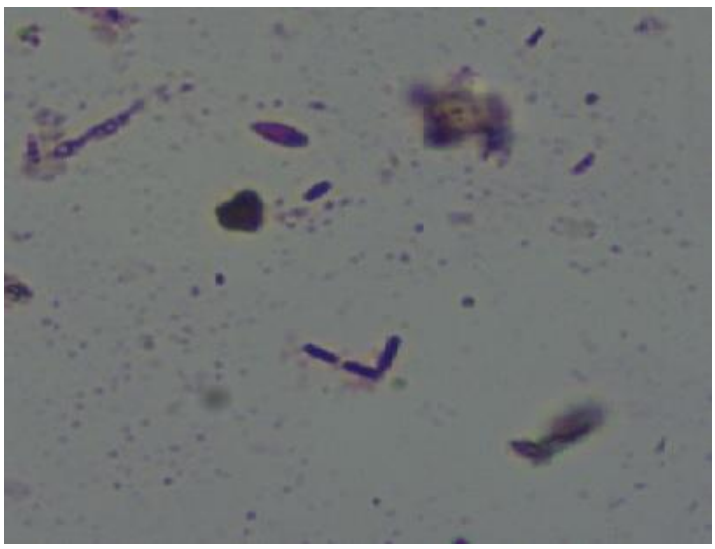

a)

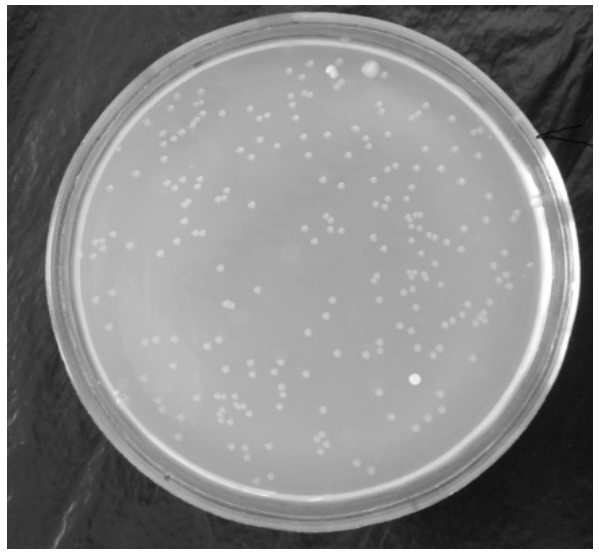

b)

Fig. 4. Colored microscopic preparation of cells of "silicate" bacteria, magnification of $1000 \times$ (a) and colony of "silicate" bacteria, grown on agar medium A-27, magnification of $30 \times(b)$ 
Acidophilic chemilithotrophic sulfur- and iron oxidizing bacteria, both mesophilic and moderately thermophilic, are present in microbiocenosis of the investigated coal in a fairly large amount. This is due to the presence of favorable conditions for their existence in the form of sulfur and iron compounds, particularly pyrite, in the composition of coal, as well as a wide range of temperatures in which this microbiocenosis is formed [6, 14, 17]. Representatives of ACB, which use bivalent iron or thiosulfate as a source of energy are quantitatively dominated. So, after seven days of cultivation, the cell count in the mesophilic association of ACB, which develops on a selective nutrient medium of $9 \mathrm{~K}$ and oxidizes $\mathrm{Fe}(\mathrm{II})$ or TS, was $(7.8 \pm 0.3) \cdot 10^{6}$ and $(3.0 \pm 0.1) \cdot 10^{3}$ cells/gram, respectively. Morphologically, the cells were gramnegative small sticks (Fig. 5a), all of which were attributed to representatives of Acidithiobacillus, in particular $A$. ferrooxidans, when talking about $\mathrm{FeSO}_{4} \cdot 7 \mathrm{H}_{2} \mathrm{O}$ as a source of energy. Cells of moderately thermophilic bacterial species of the genera Sulfobacillus and Acidithiobacillus were isolated on the appropriate selective media of $9 \mathrm{~K}^{*}$ with $\mathrm{Fe}(\mathrm{II})$ and 150a with TS after seven days of cultivating in the amount of $(3.6 \pm 0.2) \cdot 10^{6}$ and $(1.5 \pm 0.1) \cdot 10^{2}$ cells/gram, respectively. Cells of Sulfobacillus bacteria had appropriate morphological characteristics: they were round or coccus- like, gram-positive (Fig. 5b), and the Acidithiobacillus bacteria were similar to those isolated on $9 \mathrm{~K}$ medium. On the liquid nutrient medium 882 , which was recommended for the accumulation and allocation of mesophilic representatives of different species of Leptospirillum, the development of curved spiral-shaped cells was observed (Fig. 5c), their number was $(8.0 \pm 0.2) \cdot 10^{3}$ cells/gram. It is known that bacteria of the genus Leptospirillum are typical inhabitants of mines, acidic drainage waters. They can be found in microbiocenoses together with representatives of Acidithiobacillus and participate in leaching processes of metals [18].

Despite the similar morphology of Acidithiobacillus cells, the characteristics of their colonies, which grew on dense environments, differed significantly depending on the source of energy used. Thus, on an agar medium 9K with thiosulfate, the cells form irregularly-shaped crystalline colonies with metallic shine (Fig. 6a); in the presence of iron the colonies were granular and rust-colored (Fig. 6b). The energy source used is also crucial to the formation of the Sulfobacillus, Leptospirillum and Thiobacillus colonies: the appearance of the Thiobacillus colonies, which were grown on $\mathrm{Na}_{2} \mathrm{~S}_{2} \mathrm{O}_{3}$, is represented in Fig. 6a, colonies of Sulfobacillus and Leptospirillum, which were grown on $\mathrm{FeSO}_{4} \cdot 7 \mathrm{H}_{2} \mathrm{O}$, are shown in Fig. $6 \mathrm{~b}$.

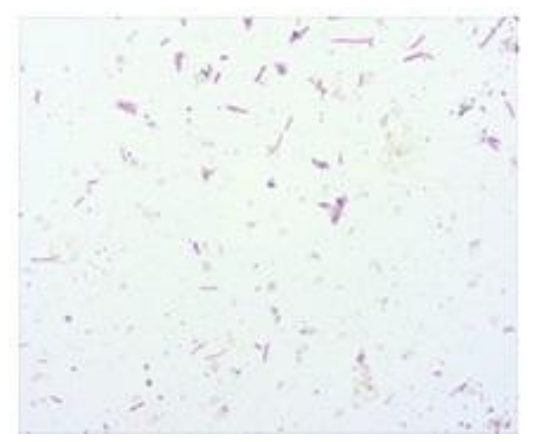

a)

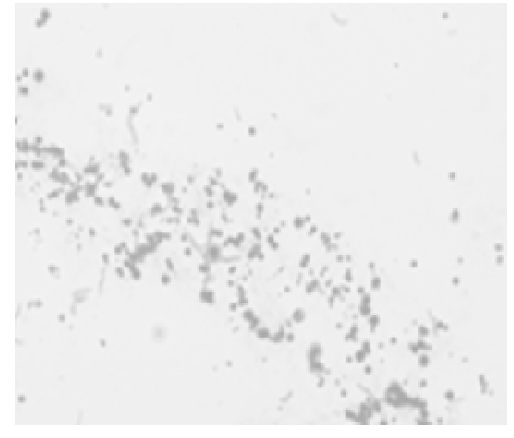

b)

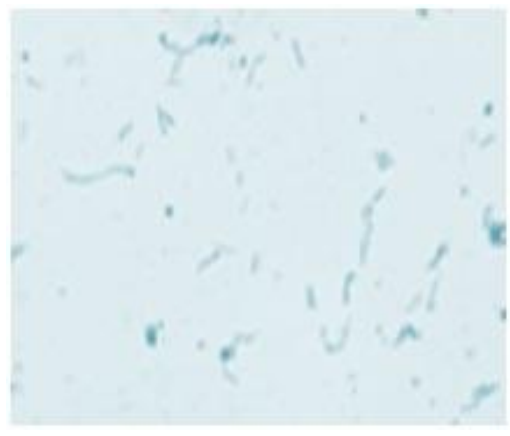

c)

Fig. 5. Colored microscopic preparation of bacterial cells isolated from the coal microbiocenosis: Acidithiobacillus (a); Sulfobacillus (b) and Leptospirillum (c). Magnification of 1000×

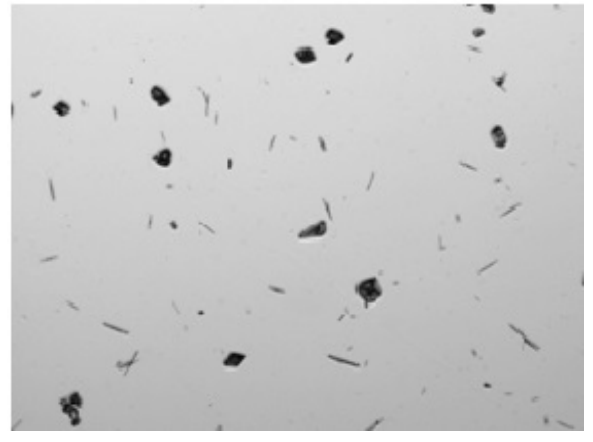

a)

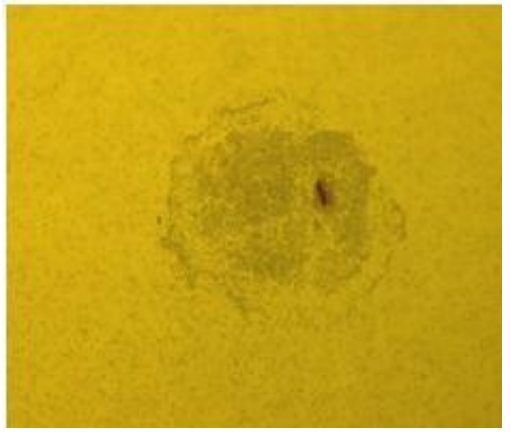

b)

Fig. 6. Colonies of Acidithiobacillus which were grown on the agarized 9K medium with thiosulfate (a) and with $\mathrm{FeSO}_{4} \cdot 7 \mathrm{H}_{2} \mathrm{O}($ b). Magnification of $30 \times$ 
Neutrophilic bacteria of the Thiobacillus genus, which oxidize sulfur and its reduced compounds, were isolated on a selective medium of Beierinck in a relatively small amount $(1.0 \pm 0.1) \cdot 10^{3}$ cells/gram. The cumulative culture after five days of cultivation was covered with a whole glossy white film formed by small gram-negative cells, arranged one-by-one or in the form of chains; on the agar medium, they formed large dark gray convex and small colorless colonies. This corresponds to the results of other researchers, who also determined the presence of Thiobacillus bacteria in the coal mines [13].

The conducted researches allowed to detect microscopic fungi, heterotrophic bacteria, neutrophilic and acidophilic chemolithotrophic bacteria, including the genera Acidithiobacillus, Sulfobacillus, Leptospirillum and Thiobacillus in the structure of microbiocenosis of coal mines of the Lviv-Volynsky coal basin. Each of the detected physiological groups of microorganisms, besides fungi, because of its vital activity and metabolism, potentially possesses the ability to desulfurize coal, since previously we received results on the extraction of metals, both rare and heavy, from the products of enrichment and combustion of coal [19]. Wherein the cultures in association showed greater activity compared to the isolated state, which is connected to common amongst microorganisms syntrophic relations, i.e. the activity during the substrate breakdown by one type of bacteria, without which the activity of another group of bacteria is either slowed down or impossible. Thus, Kuzyakina et al. [20] suggest that bacteria Acidithiobacillus thiooxidans, which are often present together with Acidithiobacillus ferrooxidans, at the expense of faster oxidation of sulfur with an indirect mechanism of bioservice, create favorable conditions for the growth of iron oxidizing bacteria. Therefore, at the next stage of research, quantitative changes in the indicators of total, pyrite and organic sulfur in coal were determined after contact with the appropriate selective nutrient medium. This allowed to draw conclusions about the activity of each individual group in the aboriginal community relative to the possible desulfurization ability (Fig. 7).

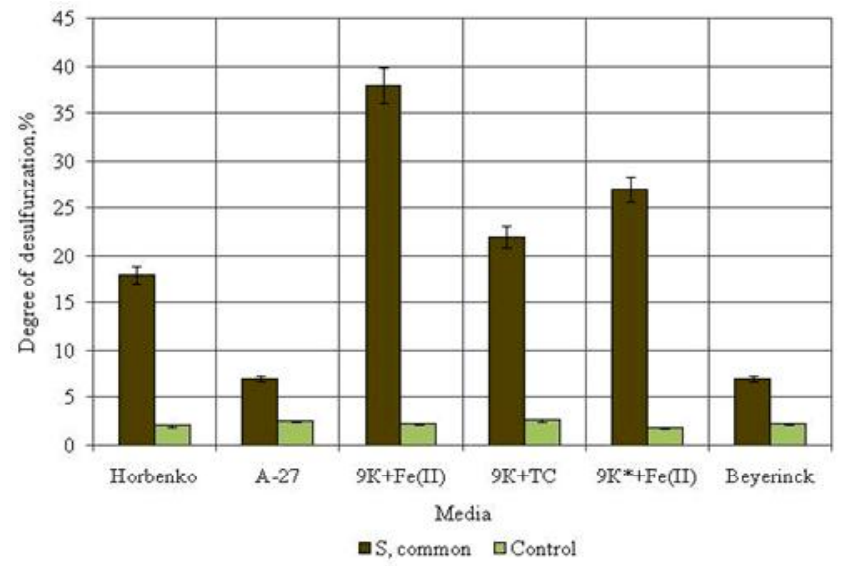

Fig. 7. The desulfurization degree of coal isolated from its microbiocenose consortia of microorganisms, which developed on selective nutrient media

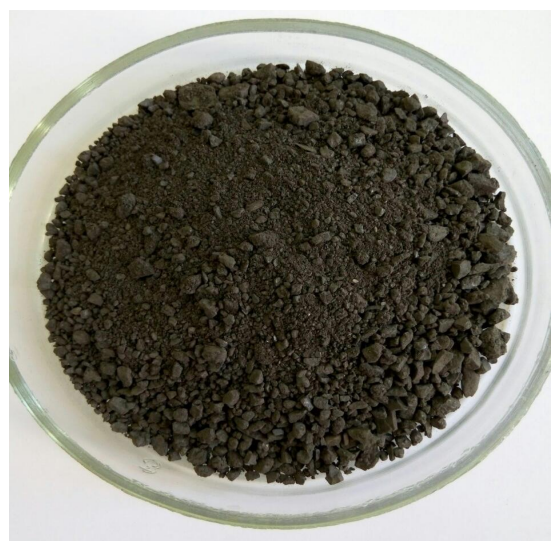

b)

a)

Fig. 8. Appearance of coal from the Lviv-Volynsky coal basin before (a) and after (b) contact with the nutrient medium A-27

As expected, the association of acidophilic chemolithotrophic bacteria, grown on $9 \mathrm{~K}$ and $9 \mathrm{~K}^{*}$ from $\mathrm{FeSO}_{4} \cdot 7 \mathrm{H}_{2} \mathrm{O}$ and $\mathrm{Na}_{2} \mathrm{~S}_{2} \mathrm{O}_{3}$ as an energy source, was shown to be the most active in the removal of sulfur from coal. After seven days of coal contacting with an appropriate cultivation medium at $\mathrm{S}: \mathrm{L}=1: 10$, the degree of desulphuri- 
zation was $24.3-36.8 \%$, and the total sulfur content was decreased to $1.81-2.16 \%$. As the analysis showed, desulfurization was mainly due to the removal of pyrite sulfur. Its content decreased to $0.43-0.86 \%$, while the organic sulfur content remained in the range of 1.00 $1.05 \%$. The activity of the "silicate" association that develops on the selective A-27 medium, as well as the neutrophilic bacteria growing on the Beyerinck medium, was low and did not exceed $7.5 \%$ for the sulfur removal, which correlates with a small number of relevant isolated associations (Table 2). However, there was an apparent change in the appearance of coal after contact with the nutrient medium A-27: grinding of the substrate indicates the destruction of the crystalline structures of the inorganic component of coal, represented largely by aluminosilicates and quartz (Fig. 8). It can be used as a preliminary processing of coal in the development of biotechnology and its desulfurization in order to increase the effectiveness of other associations, in particular, representatives of Acidithiobacillus.

The degree of coal desulfurisation by the association of heterotrophic microorganisms grown on the Horbenko medium was not very high $(17.8 \%)$, and the amount of total sulfur was decreased to $2.35 \%$. However, desulfurization was mainly due to the removal of organic sulfur. Its content decreased to $0.58 \%$, while the sulfur content of pyrite remained within $1.40 \%$. This fact indicates certain ways in the development of biotechnology for efficient sulfur removal from coal.

\section{Conclusions}

The microbioecoenosis of coal mines of the LvivVolynsky coal basin has been characterized by the presence of microscopic fungi, heterotrophic bacteria, and neutrophilic and acidophilic chemolithotrophic bacteria. The most numerous and active in relation to the sulfur removal from coal is the mesophilic association that developed in a selective nutrient medium for representatives of Acidithiobacillus, in particular, A. ferrooxidans; the degree of coal desulfurization corresponded to $36.8 \%$, mainly due to the removal of pyrite sulfur. From the point of view of removing organic sulfur, the largest and most potential is the association of heterotrophic bacteria that destroys carbon-sulfur bonds in heterocyclic sulfur compounds such as thiophene and its derivatives. During the development of biotechnology it is necessary to pay attention to the small, but promising from the standpoint of coal preliminary processing physiological group of socalled "silicate" bacteria of the Bacillus genus, capable of destroying the crystalline structures of the inorganic component of coal, represented largely by aluminosilicates and quartz. This will allow to leverage the full potential of microbiocenosis of coal for its biodesulfurization.

\section{References}

[1] Nazimko E.: Visti Donetskogo Girnichnogo Institutu, 2014, 2, 60.

[2] Tregubov D., Miroshnichenko D.: Koks i Khimiya, 2005, 6, 21.

[3] Blayda I., Vasyleva T.: Microbiologia i Biotechnologia, 2017, 3, 6. https://doi.org/10.18524/2307-4663.2017.3(39).110877

[4] Rossi G.: Adv. Biochem. Eng. Biotechnol., 2014, 142, 147. https://doi.org/10.1007/10_2013_178

[5] Karavayko G., Dubinina G., Kondrateva T: Mikrobiologia, 2006, 5, 593.

[6] Karavaiko G., Lobyreva L.: Fuel Process. Technol., 1994, 40, 167. https://doi.org/10.1016/0378-3820(94)90140-6

[7] Blayda I., Vasileva T., Baranov V. et al.: Biotechnologia Acta, 2015, 8, 56. https://doi.org/10.15407/biotech8.06.056

[8] Rawlings D.: Microb. Cell Fact., 2005, 4, 4. https://doi.org/10.1186/1475-2859-4-13

[9] Ralph F. Purdy, Joe E. Lepo, Bailey Ward: Curr. Microbiol., 1993, 27, 219. https://doi.org/10.1007/BF01692879

[10] Malik A., Ali M., Jamal A. et al.: Geomicrobiol. J., 2017, 34,

109. https://doi.org/10.1080/01490451.2016.1143538

[11] Herhard F. (Ed.): Metody Obshchei Bacteriologii, t.2. Mir, Moskva 1984.

[12] Karavayko G., Rossi Dzh., Agate A.: Centr Mezhdunarodnyh Proektov GKNT, Moskva 1989.

[13] Belly R., Brock T.: J. Bacteriol., 1974, 117, 726.

[14] Ramesh M., Anbusaravanan N., Loganathan A.: J. Pharmacy Biol. Sci., 2014, 9, 38.

[15] Liu W., Xu X., Wu X. et al.: Environ. Geochem. Health, 2006, 28, 133. https://doi.org/10.1007/s10653-005-9022-0

[16] Karavaiko G., Krutsko V., Mel'nikova E. et al.: Mikrobiologiia, 1980, 49, 547.

[17] Yang X., Wang S., Liu Y. et al.: Can. J. Microbiol., 2015, 61, 65. https://doi.org/10.1139/cjm-2014-0250

[18] Johnson D., Ghauri M., Said M.: Appl. Environ. Microbiol., 1992, 58, 1423.

[19] Blayda I.: Biotechnologia Acta, 2014, 7, 94. https://doi.org/10.15407/biotech7.05.094

[20] Kuzyakina T., Hainasova T., Levenez O.: Vestnik KRAUNTs. Nauki o Zemle, 2008, 2, 76.

Received: April 08, 2019 / Revised: April 24, 2019 / Accepted: October 30, 2019

\section{ДОСЛІДЖЕННЯ МІКРОБІОЦЕНОЗУ КАМ'ЯНОГО ВУГІЛЛЯ ДЛЯ РОЗРОБЛЕННЯ БІОТЕХНОЛОГІЧНОГО СПОСОБУ ЙОГО ДЕСУЛЬФУРИЗАЦІї}

\begin{abstract}
Анотація. Встановлено наявність мікроскопічних грибів, гетеротрофних бактерій, а також нейтрофільних $i$ ацидофільних хемолітотрофних бактерій в мікробіоценозі вугілля. Найбільш чисельною $і$ активною по відношенню до видалення піритного сульфуру є представники Acidithiobacillus. 3 точки зору видалення органічного сульфуру найбільший потенціал мають гетеротрофні бактерії. Попереднє оброблення вугілля «силікатними» бактеріями 3 роду Bacillus дає можливість максимально повно використати весь потенціал мікробіоценозу вугілля для його біодесульфурізаиіï.
\end{abstract}

Ключові слова: вугілля, мікробіоценоз, десульфурізачія, гетеротрофні бактерії, ацидофільні хемолітотрофні бактерії. 